\title{
Judicial Power Decentralization in Ethiopia: Practical Limitations and Implications on Self- governance of Regional States
}

\begin{abstract}
Ethiopia's Constitution provides for a parallel -federal and state- court system. While federal courts entertain cases of federal matter, state courts adjudicate regional matters. However, there are ambiguous issues and practical limitations relating to this judicial power decentralization, some of which have an undesirable implication on the self-governance of regional states. These are the federal versus state matter controversy, the scope of the Federal Judicial Administration Council's involvement in the nomination of state court judges, lack of standard criteria to calculate the cost regional state courts incur in exercising delegated judicial powers and the issue of cassation over cassation on state matters. Several challenges arise from the distribution of judicial authority in Ethiopia. First, regional states have done little with regard to distinguishing state matters from federal matters, and claiming reimbursement for costs they incur in exercising delegated federal judicial power. Second, the federal Supreme Court allocates nominal compensatory budget without considering the number of federal cases that are adjudicated in state courts and accordingly computing the cost incurred while state courts exercise delegated federal judicial power. Third, cassation over cassation on state matters seems to be inconsistent with the federal arrangement. These factors indicate gaps in the decentralization of judicial power which necessitate constitutional and legislative measures that can rectify these limitations commensurate with the power of regional states to exercise judicial power in regional matters.
\end{abstract}

\section{Key terms}

Judicial power $\cdot$ Federalism $\cdot$ Decentralization $\cdot$ Self-governance $\cdot$ Ethiopia

DOI http://dx.doi.org/10.4314/mlr.v13i3.2

This article is licensed under a Creative Commons Attribution-NonCommercial-

NoDerivs (CC BY-NC-ND)

\section{Suggested citation:}

Afesha, Nigussie (2019), 'Judicial Power Decentralization in Ethiopia: Practical Limitations and Implications on Self-governance of Regional States', Mizan Law Review, Vol. 13, No. 3, pp. 363-383

\footnotetext{
- Nigussie Afesha: LLB, MA, Associate Professor, College of Law and Governance, School of Law, Hawassa University, and Ph.D candidate at Andhra University, Dr BR Ambedkar College of law, India. Email: nigussie.afesha12@gmail.com

ORCID: https://orcid.org/0000-0003-4396-374X
} 


\section{Introduction}

The FDRE Constitution provides for the establishment of an independent judicial system both at federal and state levels, which is "one of the fundamental institutions of any democratic constitutional system". "This shows that the Ethiopian judicial system is designed with parallel court systems in which regional states and the federal government have their own set of independent court structures and administrations. ${ }^{2}$ Division of adjudicative responsibility is a fundamental component of Ethiopia's federal system. The Constitution establishes tiers of federal and state courts, and gives an overview of their jurisdiction leaving the details to be determined through legislation. ${ }^{3}$ These courts have specified jurisdiction in different subject matters and apply laws in their judicial competence. ${ }^{4}$

Federal courts are authorized to see cases of federal matters while state courts are entitled to handle regional matters. However, it is not adequately clear as to what constitutes a federal, and which matters are reserved to state courts. ${ }^{5}$ There are also many problematic constitutional issues arising out of distribution of judicial authority in Ethiopia's federal system. One could point out the role of the Federal Judicial Administration Council (FJAC) in forwarding its opinion on the nomination of regional court judges, the legal bases for 'empowerment' of regional first instance courts to handle federal matters (for instance in criminal and labour issues), and cases that can be adjudicated by regional courts through delegation. Other issues include whether the concept of residual power applies to justify the competence of regional first instance courts to adjudicate federal

I thank my research guide Professor V. Vijay Lakshmi (Andhra University, Dr. B.R. Ambedkar College) and Dr. Beza Dessalegn (Hawassa University, school of law) for their comments and insightful suggestions. I also thank Dr. Elias N. Stebek for his contribution toward the improvement of the article. I am further thankful for the anonymous reviewers for their comments.

\section{Acronyms:}

FJAC Federal Judicial Administration Council

HoF House of Federation

HoPR House of Peoples' Representatives

JAC Judicial Administrative Council

NNP Nations, Nationalities and Peoples

SNNP Southern Nations, Nationalities and Peoples

${ }^{1}$ Semahagn Gashu (2014), The Last Post-Cold War Socialist Federation: Ethnicity, Ideology and Democracy in Ethiopia, Ashgate Publishing Limited, USA, P. 218.

${ }^{2}$ Assefa Fiseha (2011), 'Separation of powers and its implications for the judiciary in Ethiopia', Journal of Eastern African Studies, Vol. 5, No. 4, p .704.

${ }^{3}$ See, the FDRE Constitution, Article 78(2)\&(3).

${ }^{4}$ For this reason, there is no judicial hierarchy between the federal and regional states courts.

${ }^{5}$ Assefa Fiseha (2011), supra note 2, p. 704. 
matters, and the constitutional base in demanding federal attorney license to represent a case (that involves federal matters) adjudicated in regional courts.

There is a clear constitutional provision that requires the federal government to reimburse costs incurred by regional state courts in the course of handling federal cases. However, there are no objective standards and transparent criteria in determining compensatory budget. This article explores the modes and extent of decentralization of judicial power in Ethiopia. It also examines the constitutional provisions and practical limitations relating to decentralization of judicial power, and their implications on the self-governance of regional states.

The first section of the article deals with the discourse on federal and state matters and how this can be identified and determined. The second section discusses allocation of compensatory budget for states whose regional supreme and high courts exercise delegated federal judicial power. It examines how compensatory budget is computed. Section 3 deals with the role of the Federal Judicial Administration Council in the appointment process of regional state court judges. It also explains the potential reason for such kind of arrangement. Sections 4 and 5 deal with the debate in the choice of working language in regional state courts while they exercise delegated power, attorney license in federal matters, and cassation over cassation on state matters.

\section{Federal versus State Matters: Scope and Meaning}

\subsection{Options in the distribution of judicial authority under federalism}

Federal political systems have tiers of government with powers allocated among them. ${ }^{6}$ Given the importance of distribution of power in a federal system, there is a need to define the jurisdiction (power) of the two tiers of government. These may include division of functions and governmental structures between levels of government, and this should be mirrored in the legislature, executive and judiciary. However, there is an argument that prompts a question "whether the division of power inherent in federalism applies for judicial power to the extent of requiring each order of government to have its own court system". ${ }^{7}$

In this regard, federations vary in the distribution of judicial authority and in setting the structure of courts that reflect the federal character of a polity. These variations range from federations whose constitutions allocate judicial power between the federal government and states to those federations whose constitutions subject state courts to the federal Supreme Court review. Some

\footnotetext{
${ }^{6}$ Ronald L. Watts (2008) Comparing Federal Systems, (3 ${ }^{\text {rd }}$ ed.), McGill-Queen's University Press, Montreal \& Kingston, P. 9.

${ }^{7}$ Assefa Fiseha (2006), Federalism and the Accommodation of Diversity in Ethiopia: A Comparative Study, Wolf Legal Publishers, Oisterwijk, p. 415
} 
federations (such as Germany, Switzerland and India) perceive lower federal courts "as unnecessary, expensive and likely an intrusion on the autonomy of the state governments". 8 According to this view, state courts are believed to be competent for the work required so long as appeal is guaranteed to a higher federal court. ${ }^{9}$

On the other hand, federations such as United States and Ethiopia divide judicial authority between the federal government and the states, (each with their own independent court structures and administrations), corresponding to legislative and executive functions. According to this approach, there should be dual set of courts that apply and interpret laws of the respective tiers of

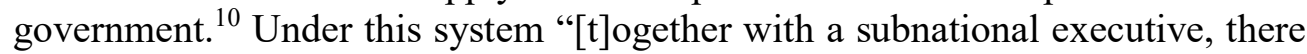
should be a subnational legislature that, within the capacities granted in the national constitution, makes the laws that affect the subnational territory" in addition to which there must be "a judiciary that enforces the laws enacted by the subnational legislature". ${ }^{11}$ In this kind of federation, unless provided otherwise, laws enacted by each level of government will be interpreted by its own judicial organ.

\subsection{Overview of federal and regional state mandates in adjudication}

In many federations, the judicial system is recognized as dual court system. The distribution of powers in federal arrangements enables federal governments and regional states to pass laws on matters that fall within the ambit of their constitutional mandate. ${ }^{12}$ Federal courts and State courts are also expected to apply and interpret laws, which are enacted by their respective levels of legislative bodies

Ethiopia's Constitution recognizes federal and regional state courts ${ }^{13}$ and allocates judicial powers to each level of courts. ${ }^{14}$ The allocation of powers is made on the basis of subject-matter jurisdiction. Federal courts adjudicate issues of national concern, while state courts are best suited to handle regional matters. ${ }^{15}$ The allocation of judicial powers avoids the overlapping of jurisdictions. In the absence of such allocation, "[s]tate and federal judiciaries

\footnotetext{
${ }^{8}$ Ibid.

${ }^{9}$ Ibid.

${ }^{10}$ Ibid.

${ }^{11}$ Maxwell A. Cameron \& Tulia G. Falleti (2005), 'Federalism and the Subnational Separation of Powers', Publius, pp. 245-271, p. 246

${ }^{12}$ Nigussie Afesha (2016), 'The Practice of Informal Changes to the Ethiopian Constitution in the Course of Application', Mizan Law Review, Vol. 10, No. 2, p. 391.

${ }^{13}$ Id., Articles 78(1) and 79(1)

${ }^{14}$ Id., Article 80

${ }^{15}$ See, Proclamation No. 25/1996, Federal Courts Proclamation, Federal Negarit Gazeta, $2^{\text {nd }}$ Year No. 13, Addis Ababa, 15 February 1996, Articles 3 and 4.
} 
not only resolve disputes but, with their overlapping jurisdictions, themselves engage in intersystem power struggles". ${ }^{16}$ Thus federal courts in Ethiopia adjudicate federal matters while regional state courts adjudicate regional matters in their own independent court structures and administrations. ${ }^{17}$ In addition to state matters, regional state courts handle federal matters through delegation by applying federal laws. ${ }^{18}$ However, what constitutes a federal or state matter is often contested. ${ }^{19}$ This raises the question as to how federal matters can be distinguished from state matters. The other question relates to whether a certain matter could possibly be a federal and state matter simultaneously.

To address these issues, one may focus on the constitutional provisions that deal with division of power. One can essentially categorise a certain matter into federal or state matter based on Articles 51, 52 and 55 of the Constitution. The logical extension of this view is that federal matters are those matters that are governed under federal laws enacted by federal legislative organ, HoPR. And, state matters are issues, which are adjudicated based on laws enacted by the State Council. This relates to the fact that federal and state courts should apply and interpret federal and state laws in their respective levels of courts. However, the statement also needs further consideration because a question can arise whether enactment of a given legislation by a certain level of government (for instance by HoPR) automatically makes the matter federal. The answer depends on the nature of the case and the exclusivity of the power given to that level of government.

It is important to note that, owing to the way the constitutional power distribution is transcribed, there are matters which are difficult to mechanically dichotomize into federal and state matters. The constitutional provisions that deal with division of power perhaps might not fully answer issues relating to the federal or state matter taxonomy. Upon careful scrutiny of the Constitution, there are several matters, which seem to fall under the category of federal matters even though they are potentially termed as state matters. The mere inclusion of a certain matter in Articles 51 or 55 of the FRDE Constitution does not thus invariably render it federal matter. Such claim may have negative repercussion on the scope of constitutional powers of the regions.

\footnotetext{
${ }^{16}$ John W. Winkle III (1974), 'Dimensions of Judicial Federalism', Annals of the American Academy of Political and Social Science, Vol. 416, No 1, p. 68.

${ }^{17} \mathrm{See}$, the FDRE Constitution, Article 80.

${ }^{18}$ It should be noted that space of delegation of federal courts jurisdiction to the regional state courts is restricted to state High courts. The constitution does not contain a structural and recognized place for regional first instance courts on delegated power.

${ }^{19}$ Assefa Fiseha (2011), supra note 2, p 704.
} 


\subsection{Adjudication in land (resource) utilization, contracts and taxation}

The mandate to enact specific laws on the utilization of land and other natural resources is given to the HoPR. ${ }^{20}$ On the other hand, regional states are constitutionally authorized to administer land and other natural resources in accordance with federal laws. ${ }^{21}$ A question arises whether the law that governs utilization of land and other natural resources is a federal matter or a state matter. If certain cases (that involve disputes on utilization of land and other natural resources) appear in regional state courts, an issue can arise whether state courts would handle the case as state matter or through delegation. The Constitution allows regional states to execute federal laws on land and other natural resources in the course of which regional state courts apply federal land laws including other natural resource laws. Under such settings, their competence cannot be considered as delegated jurisdiction. Thus, it can be argued that the mere enactment of certain legislation by the HoPR does not make an issue a federal matter so long as the application and interpretation of such laws are constitutionally granted to regional states.

There are also several laws, which are difficult to categorise either as laws enacted by federal government or state council, or whether the power is a federal or state matter through reference to the Constitution. One can mention laws which were enacted during the Imperial period, and that are being applied in federal and state courts. Examples in this regard are laws that govern persons, property, contract, succession, tort and others for which it is difficult to cite clear constitutional provision that determines whether these issues are federal or regional state matters. This evokes the question whether regional courts are empowered to see contract disputes as regional matter.

In this regard, Mehari argues that contract law falls within the jurisdiction of the regional state, and cases that involve contract issues are adjudicated by the State Courts. ${ }^{22}$ Yet, there are questions that remain unanswered as to whether adjudication of contracts falls under the exclusive jurisdiction of the states (as a constitutional mandate) or as a residual power of the state, which is left undefined. The federal government has been working to come up with draft laws in some of these matters including property and contract laws. ${ }^{23}$ It is to be noted that there are many issues in contractual disputes that may have regional and national dimensions.

\footnotetext{
${ }^{20}$ FDRE Constitution, Article 55(2)(a).

${ }^{21}$ Id., Art. 52(2)(d).

${ }^{22}$ Mehari Redae (2015), 'Cassation over Cassation and its Challenges in Ethiopia', Mizan Law Review, Vol. 9, No.1, p. 175.

${ }^{23}$ The office of Federal Attorney General has released its engagement in preparing draft laws on person, property, contract and succession law.
} 
There are also matters which are not allocated exclusively either to the centre or the regional state. ${ }^{24}$ In this regard, one can mention laws, which have direct and indirect relation with social, economic and development matters. There are issues that concurrently constitute federal and regional matters. The essential provision to be cited in this regard is Article 98 of the Constitution that gives the federal government and states the legislative and executive power over concurrent taxation. However, the federal government has been empowered exclusively to legislate and execute laws with respect to concurrent power of taxation while the regional states are entitled for their share. ${ }^{25}$

If tax dispute on issues that fall under the concurrent power of taxation appears in a regional state court, a question can arise whether the court entertains the case as delegated power or shared power. The Constitution seems to have envisaged that federal and regional states shall execute their respective tax laws that are enacted based on their concurrent power of taxation. This shows that regional state courts can have jurisdiction relating to laws enacted on the basis of the concurrent taxation regime, and they can assume delegated jurisdiction to adjudicate tax disputes that involve federal tax laws.

\subsection{Matters under federal jurisdiction}

There are matters that the Constitution gives exclusively to the federal government; but, in practice (and upon the permission of the HoPR via a proclamation), the laws are applied in the first instance courts of regional states. In this regard, legislative and executive power over penal and labour laws is given to the federal government under Article 55(5)\&(6) of the Constitution.

The Constitution allows delegation of the power to exercise Federal High Court and First Instance Court jurisdiction to regional state Supreme Courts and High Courts respectively. It does not extend such delegation to First Instance Courts of regional states (to see and solve cases that involve federal matters). There seems to be variation relating to labour law and criminal cases. The Labour Proclamation gives the mandate to see and decide -certain federal cases- to First Instance Courts of regional states. Accordingly, First Instance Courts of regional states can have delegated jurisdiction to settle and determine selected labour cases such as disciplinary measures including dismissal, claim related to termination of employment contract, remuneration, leave and

\footnotetext{
${ }^{24}$ Assefa Fiseha (2006), 'The Theory versus Practice in the Implementation of Ethiopia's Ethnic Federalism', in the Devid Turton (ed.), Ethnic Federalism: The Ethiopian Experience in Comparative Perspective, Ohio and Addis Ababa University Press, p. 141

${ }^{25}$ Nigussie Afesha, supra note 12, pp.368-369
} 
employment injury. ${ }^{26}$ The Proclamation assigns similar jurisdiction to the federal and State First Instance Courts. The authorization of federal and state First Instance Courts to review and decide similar labour cases is inconsistent with the Constitution which states that delegation of power to exercise federal First Instance Court jurisdiction is given to High Courts of regional states.

The other related issue that needs to be seen is the power of the HoPR to enact specific laws concerning the penal code. It is the HoPR that has the power to enact specific laws concerning the penal code. ${ }^{27}$ The States may, however, enact penal law on matters that are not specifically covered by federal penal law. ${ }^{28}$ This shows that since the penal code is enacted by the HoPR, the power to apply and interpret the existing penal code is the exclusive power of federal judicial organs. The supreme and high courts of regional states may apply and interpret the penal code because the supreme and high courts of regional states are vested with the power to exercise Federal High Court and First-Instance Courts jurisdiction respectively. ${ }^{29}$

Unlike labour law, the current Criminal Code does not give power to First Instance Courts of regional states to interpret and apply the federal criminal code. One may inquire into the legal grounds as to how regional first instance courts get the power to handle criminal matters, and the interests that are being promoted by allowing regional first instance courts to adjudicate criminal matters. Proclamation No. 25/1996 does not authorize first instance courts of regional states to entertain federal matters. ${ }^{30}$ As the Proclamation merely lists the civil and criminal cases that shall be adjudicated by federal courts, this implies that state courts can see (in their delegation capacity only) those civil and criminal matters that are listed in the Proclamation.

One can argue that civil and criminal cases which are not listed as federal matters in the Proclamation fall within the ambit of regional state courts, and

\footnotetext{
${ }^{26}$ See, Proclamation No.1156/2019, Labour Proclamation. Art 139(1) reads as follows: "The labour division of a Federal and Regional First Instance Court shall have jurisdiction to settle and determine the following and other similar individual labour dispute(a) disciplinary measures including dismissal (b) claims related to the termination of employment contracts (c) claims related to hours of work, remuneration, leaves and rest day (d) claims related to the issuance of certificate of service and clearance (e) claims pertaining to employment injury, transfer, promotion, training and other similar issues; (f) Unless otherwise provided in this Proclamation, suits pertaining to violations of provisions of this Proclamation."

${ }^{27}$ FDRE Constitution, Article 55(5).

${ }^{28}$ Id., Article 55(5).

${ }^{29}$ Id., Art 80(2) \&(4).

${ }^{30}$ See, Proclamation No. 25/1996, Federal Courts Proclamation, Federal Negarit Gazeta, $2^{\text {nd }}$ Year No. 13, Addis Ababa, 15 February 1996, Article 3.
} 
they have to be adjudicated by state courts. ${ }^{31}$ According to Abebe, for example, civil and criminal cases which are not specifically reserved for federal courts are considered as a 'residual power' of state courts. ${ }^{32}$ The question is whether such allocation of 'residual power' is in tandem with the Constitution. In spite of such counter arguments, we can observe that the Proclamation has not exhaustively enumerated the jurisdiction of federal courts, and it has left the rest to be adjudicated as residual judicial power of the regional state courts.

In the SNNP regional state, for example, Wereda courts have civil and criminal jurisdiction over matters that fall under the Awraja and Wereda courts pursuant to the civil and criminal codes and other laws. ${ }^{33}$ These powers of the Wereda courts have been amended through Proclamation No 130/2009 which is enacted to redefine the powers of the regional state courts. ${ }^{34}$ Pursuant to this Proclamation, Wereda courts have jurisdiction over cases involving an amount up to three thousand $(3,000)$ Ethiopian Birr; or cases whose value cannot be expressed in money; and cases appealed from social courts. ${ }^{35}$

The new Proclamation does not state whether Wereda courts will continue assuming their material jurisdiction over criminal matters. This triggers the question whether the Proclamation revokes the criminal jurisdiction of Wereda courts. The answer should be in the negative because social courts have material jurisdiction over limited criminal matters ${ }^{36}$ over which Wereda courts shall have appellate jurisdiction. ${ }^{37}$

Although wereda courts have no constitutional base to entertain criminal cases, they have been handling civil and criminal cases that fall within their ambit and not listed in the Proclamation as federal civil and criminal matters (to

${ }^{31}$ For instance, Yoseph Aemro supported this view at 'Training of Trainers' which was held from October 7-10, 2013, organized by Addis Ababa University Center for Human Rights.

${ }^{32}$ Abebe Mulatu, (2001), 'The Court System and Questions of Jurisdiction under the FDRE Constitution and Proclamation 25/26' in Proceedings of the Symposium on the Role of Courts in the Enforcement of the Constitution (Addis Ababa: Birhanena Selam, p.130.

${ }^{33}$ See Proclamation 43/2002, Revised Courts Proclamation of the Southern Nations, Nationalities and Peoples Regional State, Debub Negarit Gazeta, $7^{\text {th }}$ Year No 10, Awassa, 20 April, 2002, Article 7.

${ }^{34}$ See, Proclamation No 130/2009, Re-revised Courts Proclamation No $130 / 2009$ of the Southern Nations, Nationalities and Peoples Regional States, Debub Negarit Gazeta, $8^{\text {th }}$ Year No 4, Hawassa, Nov.10/2009, Article 4.

${ }^{35}$ Ibid

${ }^{36}$ See, Proclamation No. 18/1998, Proclamation for the Establishment of Kebele Social Courts of the SNNP Regional State, Debub Negarit Gazeta, $3^{\text {rd }}$ Year No. 3, Hawassa, $14^{\text {th }}$ March, 1998, Article 19(1).

${ }^{37}$ See, Proclamation No 130/2009, Article 4. 
be adjudicated by federal courts). The silence of Federal Supreme Court Cassation Bench and/or regional supreme courts seems to be associated with the inaccessibility of regional high courts to see criminal matters at Wereda level.

It should be noted that the discourse on federal and state matters is important because it allows regional states to spend their time and regional resources in those matters over which they have constitutional mandate. It should also be noted that regional state courts are entitled to get compensatory budget when they adjudicate federal matters.

\section{Provision of Compensatory Budget for Exercising Delegated Federal Jurisdiction by State courts}

As stated earlier, federal and regional governments have jurisdiction over federal and regional state matters respectively. In the course of these functions, the federal government is given the authority to establish Federal High and First-Instance Courts in different parts of the country. Nevertheless, until these courts are established at regional state levels, state Supreme and High courts shall (in addition to matters under their exclusive mandate), exercise the jurisdictions of federal High Court and First-Instance Court respectively. ${ }^{38}$

The Constitution states that the budget of Supreme and High Courts of a regional state shall be determined by the respective State Council. ${ }^{39}$ Article 79(7) of the FDRE Constitution further provides that the "House of Peoples" Representatives shall allocate compensatory budget for States, whose Supreme and High courts concurrently exercise the jurisdiction of the Federal High Court and Federal First Instance Courts." This is in tandem with the constitutional provision which requires government at federal and regional state levels to bear the financial cost necessary to carry out all responsibilities and functions assigned to them by law.

Unless otherwise agreed upon, the federal government shall bear the financial expenditures required for the carrying out of Federal High Court and of the First-Instance Courts jurisdiction in the state courts. ${ }^{40}$ Hence, the federal government shall defray the costs incurred by courts of regional states, and the regional state should not draw up budget for activities which are not constitutionally assigned to them. If regional states continue financing the budget to carry out delegated power form their own source of revenue, they will face budget constraints thereby becoming financially dependent on grants which will be given to them from the central government.

\footnotetext{
${ }^{38} \mathrm{See}$, the FDRE Constitution, Article 78(2).

${ }^{39}$ Id., Article 79(7).

${ }^{40}$ See, Id., Article, 94(1).
} 
An issue may arise whether courts of regional states are entitled to get compensatory budget where the federal government establishes federal high and first instance courts in the regions. As Gedion and Abduletif noted, the exercise of Federal High and First-Instance Courts jurisdictions in regional States Supreme and High courts should be seen as temporary arrangement. ${ }^{41}$ This is because the Constitution gives the HoPR the option to establish Federal High and First-instance courts nationwide or in some parts of the country. ${ }^{42}$ The establishment of Federal High and First-Instance Courts in the regional states puts an end to the delegation of judicial powers to state $\operatorname{courts}^{43}$ upon which the regional judiciaries are deemed lacking technical competence over federal matters. ${ }^{44}$

Federal High Courts are established in Afar, Benshangul, Gambella, Somali and SNNP regional states, and in effect, supreme courts of these five regional states supreme courts lack technical competence to exercise Federal High Court judicial jurisdictions given to state courts through delegation. ${ }^{45}$ Yet, the Federal Supreme Court Cassation Division has, in one of its decisions, rendered binding interpretation regarding the effects of establishing Federal High Court in the five regional states in relation to their delegated powers. ${ }^{46}$ According to this decision, the establishment of Federal High Court in the five regional states only revokes the power of the Supreme Courts of regional states to exercise the first instance jurisdiction of the federal High Court though delegation. The Federal Cassation decision shows that the establishment of Federal High Court in the five regional states does not altogether take away the power of the regional Supreme courts to see federal cases referred from the state High courts through appeal. ${ }^{47}$ Supreme courts will thus continue exercising the appellate jurisdiction of the Federal High Court, which is an aspect of delegated judicial jurisdiction, as this fact is taken into consideration in the allocation of compensatory budgets. ${ }^{48}$

${ }^{41}$ Gedion T. Hessebon and Abduletif k. Idris (2017), 'The Supreme Court of Ethiopia: Federalism's Bystander', in Nicholas Aroney and John Kincaid (eds.) Courts in Federal Countries: Federalists or Unitarists? p. 178.

${ }^{42}$ See, the Amhara Regional State Constitution, Article 78 (2).

${ }^{43}$ Gedion T. Hessebon and Abduletif K. Idris, supra note 41, p. 178p

${ }^{44}$ Ibid.

${ }^{45}$ See Proclamation No. 322/2003, the Federal High Court Establishment Proclamation, Art 2.

${ }^{46} \mathrm{See}$, the decision of the Federal cassation Division on a case between Ethiopia Insurance Company versus Ato Solomon Yakob, rendered on Nov. 11, 2020, File number, 54577, Volume 12, pp. 457-450

${ }^{47}$ Ibid.

${ }^{48}$ Some even argue that the state courts that adjudicate federal matters collect court fees from civil cases and financial penalties from criminal cases, and this has been taken into 
Following the constitutional obligation of HoPR to allocate compensatory budgets to reimburse the cost states incur in the course of exercising Federal High Court and Federal First-Instance Courts jurisdictions, state constitutions empower different organs to claim compensatory budgets. In this regard, the Amhara Regional State Constitution empowers the president of the Supreme Court $^{49}$ whereas SNNP regional state gives this mandate to the state Supreme Court. ${ }^{50}$ The Oromia Regional State Constitution states that expenses incurred by Oromia regional state courts while exercising delegated federal jurisdictions, shall be borne by the federal government. ${ }^{51}$ With regard to the assessment of the compensatory budget, Solomon argues that " $[\mathrm{u}]$ nder the delegation schemes, the federal government should reimburse the share of each state based on the actual costs incurred in performing the delegated function". ${ }^{52}$ From this perspective, the reimbursement is not grant per se, and can be assessed based on the number of cases (which involve federal matters) that are entertained by regional courts.

There was failure to pay compensatory budget "to reimburse the cost incurred by states" in spite of "an explicit constitutional requirement" ${ }^{33}$ until the recent practice of the Federal Supreme Court to compensate regional states whose supreme and high courts exercise federal judicial jurisdiction. ${ }^{54}$ However, there is no directive issued by the Federal Supreme Court that regulates the determination and allocation of compensatory budget payable to states courts. ${ }^{55}$ The table below shows the amount of annual compensatory budget that the Federal Supreme Court provides for the nine states supreme courts since 2018.

consideration as a compromise for the nominal compensatory budget allocated to the state courts while exercising delegated Federal matters. The author is the opinion that the suggestion is legitimate but it should be seen in line with Art 94(1) of the FDRE Constitution that states unless otherwise agreed upon, the financial expenditures required for the carrying out of any delegated function by a State shall be borne by the delegating party. This preposition seems to give the impression that court fees and financial penalties are taken into consideration from the outset.

${ }^{49}$ Amhara Regional State Constitution, Article 68 (7).

${ }^{50}$ SNNP regional state constitution, Article 75 (7).

${ }^{51}$ Oromia Regional State Constitution, Article 63(6).

${ }^{52}$ Solomon Negussie (2008), Fiscal Federalism in the Ethiopian Ethnic-based Federal System, Rev. ed. Netherlands Wolf legal publishers, p. 236.

${ }^{53}$ Ibid.

${ }^{54}$ Interview with Ato Goshiye Damitew, Court Manager, Federal Supreme Court, October 3, 2019, Addis Ababa

${ }^{55}$ Interview with Ato Boja Tadesse, Head of Office of the Federal Supreme Court President, October 3, 2019, Addis Ababa. 


\begin{tabular}{|c|c|c|c|c|c|}
\hline \multirow[b]{2}{*}{ No } & \multirow{2}{*}{ State Supreme court } & \multirow{2}{*}{$\begin{array}{c}\text { Budget } \\
\text { requested } \\
\text { by the state } \\
\text { Supreme } \\
\text { courts }\end{array}$} & \multicolumn{3}{|c|}{$\begin{array}{l}\text { Budget allocated to the nine state } \\
\text { Supreme courts }\end{array}$} \\
\hline & & & 2018 & 2019 & 2020 \\
\hline 1 & Tigray Supreme court & $1,446,500.00$ & $394,722.00$ & $394,722.00$ & $638,720.00$ \\
\hline 2 & Oron & $8,418,55$ & $394,722.00$ & $394,722.00$ & $638,720.00$ \\
\hline 3 & $\mathrm{Amh}$ & Not req & $394,722.00$ & $394,722.00$ & $638,720.00$ \\
\hline 4 & SNN & & 394,7 & $394,722.00$ & $638,720.00$ \\
\hline 5 & Gambella Supreme court & Not requested & $284,222.00$ & $284,222.00$ & $484,224.00$ \\
\hline 6 & Afar Supreme court & Not requested & $284,222.00$ & $284,222.00$ & $484,224.00$ \\
\hline 7 & $\begin{array}{l}\text { Benishangul Gumuz } \\
\text { Supreme court }\end{array}$ & Not requested & $284,222.00$ & $284,222.00$ & $484,224.00$ \\
\hline 8 & Hariri Supreme court & Not requested & $284,222.00$ & $284,222.00$ & $484,224.00$ \\
\hline 9 & Somalia Supreme court & $3,422,079.58$ & $284,222.00$ & $284,222.00$ & $484,224.00$ \\
\hline
\end{tabular}

Source, Federal Supreme Court Finance Directorate

As the table above indicates, the nine supreme courts of regional states are placed under two categories. The four supreme courts (Amhara, Oromia, SNNP and Tigray State Supreme Courts), are clustered into one category, with identical compensatory budget allocation irrespective of the number of federal cases adjudicated in the courts of the regional states. On the other hand, the Supreme Courts of Gambela, Afar, Benishangul/Gumuz, Hariri, Somali regional states are grouped into another category, and granted identical compensatory budget. Moreover, even though Federal High Courts are established in the Afar, Benshangul Gumuz, Gambella, Somali and SNNP regional states, the compensatory budget does not take this factor into account.

The Federal Supreme Court provides compensatory budget for the supreme courts of nine regional states without taking into consideration claims of compensatory budget from supreme courts of regional states or analyzing the number of federal cases seen in the nine states Supreme and High courts. ${ }^{56}$ This problem is expected to be addressed upon the enactment of the Federal Courts Draft Proclamation which requires the preparation and submission of reports along with supporting data regarding federal cases seen in the Supreme and High courts of regional states. ${ }^{57}$ The Draft Proclamation also empowers the President of the Federal Supreme Court to decide on the compensatory budget request of the state courts relating to their exercise of federal judicial power by delegation. ${ }^{58}$

\footnotetext{
${ }^{56}$ Interview with W/ro Emebet W/Geworgis, Federal Supreme Court, Finance Directorate, Director, October 3, 2019, Addis Ababa

${ }^{57}$ Draft Federal Court Proclamation, Art 17(1)(e), on file with author.

${ }^{58} \mathrm{See}$, the Draft Federal Court Proclamation, Art 17(1)(f).
} 
Apportioning compensatory budget among Supreme Courts of regional states without valid standards and assessment seems to have been based on the assumption that courts of regional states handle federal cases as their 'ordinary judicial function'. ${ }^{59}$ This seems to have mainly emanated from the wrong association of compensatory budget with the general grant transfers from the federal government to regional states.

It is to be noted that the Constitution reserves limited financial resources to regional states that undertake activities based on their constitutional mandate, and the reluctance of the federal government to provide compensatory budget may further expose regional states to financial constraints. This challenge can indeed impair the competence of regional states to provide necessary public services for residents of the region using the revenue collected from regional community. This in return increases the regional state's dependence on national transfers, in the form of conditional grant, to deliver basic social services and regional administration of justice over state matters, thereby adversely affecting state autonomy.

\section{FJAC Role on the Appointment of Regional State Court Judges vs. Regional State Self-autonomy}

The idea of decentralization of judicial power not only empowers the federal government and states to define the organization, hierarchy and administration of courts in their respective territory, it also gives authority to both tiers of government the power to decide how to recruit, appoint and promote judges to their respective courts. It also includes the power to decide which institution /organ/ undertakes the recruitment, appointment, promotion and transfer of judges in their respective courts. The capacity of regional states to make recruitment, appointment, promotion and transfer of judges for state courts is an integral part of their self-governance.

The Judicial Administrative Council (JAC) is a responsible organ for the recruitment, appointment, promotion and transfer of judges. ${ }^{60}$ By virtue of the Constitution, judicial administrative council is established at federal and state levels. Although the Constitution seems to tacitly limit the establishment of JAC at Federal and State levels, JAC has also been established at municipal level. ${ }^{61}$

\footnotetext{
${ }^{59}$ Interview with Ato Mate Megene, President of Hawassa of City High Court, Hawassa, 15 April, 2018.

${ }^{60}$ See, the FDRE Constitution, Article 79(4)

${ }^{61}$ Assefa Fiseha (2010), 'The Concept of Separation of Powers and Its Implication on the Role of the Judiciary in Ethiopia', in the Assefa Fiseha and Getachew Assefa (eds.) Institutionalizing Constitutionalism and the Role of the Law: Towards a Constitutional Practice in Ethiopia, Ethiopia Constitutional Law Series, Vol. 3, p. 35.
} 
One may question the constitutional base of establishing JAC at municipal level. Yet, some of the regional state constitutions envisage JAC at municipal level. For instance, the SNNP Regional State Constitution has declared the establishment JAC at zone and special wereda levels. ${ }^{62}$ This is also replicated in the SNNP Regional State Judicial Administration Commission Establishment Proclamation. ${ }^{63}$

The Constitution states that the president and vice-president of the regional Supreme Courts are appointed by the State Council upon the recommendation of the Chief Executive of the State. ${ }^{64}$ One may also expect the same trend in the appointment of Supreme, High and First Instance courts judges of regional states. The appointment of judges for regional state courts is approved by the state's Judicial Administration Council. However, the Constitution requires the State Judicial Administration Council, in the course of selection, to solicit and obtain the views of the Federal Judicial Administrative Council (FJAC) before submitting the names of nominees to the State Council. The FJAC Establishment Proclamation states that one of the main duties of the FJAC is to forward its opinion on the list of regional Supreme and High Court candidate judges, submitted to it by regional judicial administration councils ${ }^{65}$ In this regard, state courts have been soliciting the opinion of the FJAC on the list of nominees for regional Supreme and High Court judgeship. ${ }^{66}$

After having obtained the views of the FJAC, the State Judicial Administration Council (SJC) sends the list of nominees to the State Council. The SNNP regional state JAC, in addition to the opinion of the FJAC, is also required to solicit and obtain the views of the Zonal Judicial Administration Commission before submitting the nominees to the State Council. ${ }^{67}$ Since it is embodied the FDRE Constitution, the regional states have to adhere to this constitutional provision, and the FJAC is also responsible to give its views and

${ }^{62}$ See, the SNNPR Regional State Constitution, Article 76(3).

${ }^{63}$ See, Proclamation No.12/1997, SNNP Regional State Judicial Administration Commission Establishment Proclamation, Debub Negarit Gazetta, $2^{\text {nd }}$ year, No. 2, Awassa, $28^{\text {th }}$ February, 1997, Articles 3 and 6.

${ }^{64}$ FDRE Constitution, Article 81(3).

${ }^{65}$ See, Proclamation No. 684/2010, Amended Federal Judicial Administration Council Establishment Proclamation, Article 6(e).

${ }^{66}$ Interview with Ato Henok Mamo Guyale, Judicial Administration Support Work Process Coordinator at the City High Court, Hawassa, 16 April, 2018

${ }^{67}$ See article 76(3) of the SNNP Regional State Constitution cum. Article 6 of Proclamation No.12/1997, SNNPR Regional State Judicial Administration Commission Establishment Proclamation, Debub Negarit Gazetta, $2^{\text {nd }}$ year, No.2, Hawassa, $28^{\text {th }}$ February, 1997. 
recommendations to the regional states. ${ }^{68}$ It should be noted that the obligation of the State Judicial Administration Council to obtain opinion of the FJAC will be waived if FJAC does not submit its views within three months thereby enabling the State Council to grant the appointments upon the recommendation of the state Judicial Administration Council alone.

One may associate FJAC participation in the selection process of regional state Supreme and High courts judges with the authorization of state courts to exercise federal judicial jurisdictions. ${ }^{69}$ This can be justifiably inferred from the non-participation of the FJAC in the nomination of judges for regional state first instance courts. Since the state Supreme and High courts exercise judicial jurisdiction of the federal High and First-Instance courts respectively, the federal government wants to check the professional competence of the judges to handle delegated federal jurisdiction. However, the scope of FJAC's power in this regard is limited to forwarding opinion on the nomination of judges for the Supreme Court and High court of regional states. The ultimate power for approval is reserved to the state legislature. ${ }^{70}$ This implies that the State Council has the power to reject the opinion of the FJAC on valid grounds.

Yet one can argue that the involvement of FJAC on the nomination of state courts judges may seem to be inconsistent with the spirit and logic of the federal arrangement established in the Constitution. Second, although the final word of approval is reserved to the state councils, due to the centralization trend observed in Ethiopia's federal arrangement, it is highly unlike state councils to resist the opinion of (position taken by) the FJAC. An equally important point that needs to be reflected upon relates to the role of FJAC in the nomination of State First-Instance courts judges. It is clear that the state Judicial Administration Council has no obligation to solicit and obtain the views of the FJAC on candidate judges for State First-Instance courts. As Christophe Van der Beken states, regional State Council can appoint state first instance court judges only upon the recommendation of a regional state's Judicial Administration Council. Despite this clear constitutional stipulation, however, the Constitutions of Oromia and Somali regional states require their respective State Judicial Administration Commissions to solicit and obtain the views of the FJAC on the nominees of judges to be appointed for State First-Instance courts. ${ }^{71}$

\footnotetext{
${ }^{68}$ Berhanu Gutema Balcha (2009), Constitutionalism in the Horn of Africa: Lesson from the New Constitution of Ethiopia, DIIPER \& Department of History, International and Social Studies Aalborg University, p. 13.

${ }^{69}$ Christophe Van der Beken (2017) Completing the Constitutional Architecture: A Comparative Analysis of Sub-National Constitution in Ethiopia, Addis Ababa University Press, p.137

${ }^{70}$ Assefa Fiseha, The Concept of Separation of Powers, supra note 61, p. 36.

${ }^{71}$ Christophe Van der Beken, supra note 69, p. 137.
} 
As Tsegaye noted, "[i]n a federal polity, because there is dual constitutionalism (often reinforced by the existence of at least two constitutional texts), the state constitutions are also used to reaffirm, explain, and elaborate on state powers that are 'granted' or 'left' to the states by the Federal constitution". ${ }^{72}$ Otherwise, such move must be forbidden on the basis of protecting the powers (and functions) of the states and to defend its constitutionally guaranteed autonomy.

The process of appointment of a regional state court judge starts from vacancy announcement based on which the state Judicial Administration Council selects candidates that satisfy the minimum requirements. After having examined documents and other procedures, it sends list of nominees for FJAC's opinion to obtain opinion before the list is sent to the State Council for approval. Although the draft Federal Judicial Administration Proclamation -which is proposed to replace the existing Federal Judicial Administration Proclamation Council Establishment Proclamation- has made changes in the criteria for nomination of judges and other issues, the proposed amendment could help the judiciary to exercise its judicial function free from internal and external influences. Yet, the involvement of the FJAC in the appointment of regional state court judges undermines the move to build an independent judiciary in the states and erodes the rights of the regional states to determine the operation of the regional courts by their own in the context of self-government.

\section{Working Language in Delegated Judicial Authority and Attorney License in Federal Matters}

Ethiopia houses a plurality of languages ${ }^{73}$ and cognizant of this fact, the FDRE Constitution gives the NNPs right to develop their language. ${ }^{74}$ The Constitution also allows all regional states to determine by law their respective working languages. ${ }^{75}$ Accordingly, every regional state determines its working language

72 Tsegaye Regassa (2009), 'Sub-national Constitutions in Ethiopia: Towards Entrenching Constitutionalism AT State Level', Mizan Law Review, Vol. 3, No.1, p.35.

${ }^{73}$ Andreas Eshete (2003), Ethnic Federalism: New Frontiers in Ethiopian Politics, First National Conference on Federalism, Conflict and Peace Building (Addis Ababa, United Printers), p. 144.

${ }^{74}$ Lovise Aalen (2006), 'Ethnic Federalism and Self-Determination for Nationalities in a Semi-Authoritarian State: the Case of Ethiopia', International Journal on Minority and Group Rights, Vol. 13, p. 256.

${ }^{75}$ Assefa Fiseha (2012), 'Ethiopia's Experiment in Accommodating Diversity: 20 Years' Balance Sheet', Regional \& Federal Studies, Vol. 22, No. 4, p. 444. 
under its regional constitution. ${ }^{76}$ In some cases, zonal administration councils are also allowed to choose their working languages. ${ }^{77}$ The Constitution permits regional states to use their languages for administrative matters. ${ }^{78}$ This suggests that institutions (including the judiciary) of a regional state can use a working language different from the federal working language.

An issue arises whether regional state courts can use their respective working languages in exercising constitutionally delegated federal judicial authority or whether they are obliged to use the working language of the federal government. As Gedion and Abdulatif stated:

Although these courts are applying federal law and acting as federal courts in exercising a delegated power, they normally do not use the working language of the federal government; instead, they use the working language of their respective states. This is particularly the case in states and sub-state autonomous administrative units that have working languages different from the federal working language. The matter is further complicated because most of these cases end up before the Federal Supreme Court for appellate or cassation review where Amharic is the working language. ${ }^{79}$

Another recurrent issue relates to whether attorney license issued in regional states can be acceptable to represent federal cases at courts of regional states that are adjudicated based on delegated federal judicial authority. For example, the proclamation which regulates the licensing and administration of advocates and paralegals in the SNNP Regional State, does not allow an advocate to provide services in federal cases adjudicated at state courts. ${ }^{80}$

One may question the rationale for requiring attorneys at law (who represent federal cases) to produce a federal license. It is to be noted that the judges in the courts of regional states are appointed by state councils and handle both federal and state matters in the same courtrooms. One may, for example, take the instance where a high court judge who was adjudicating federal matters in a regional state court resigns and provides attorney service. A question thus arises whether this former judge of the high court should have federal license to represent federal cases in state courts.

\footnotetext{
${ }^{76}$ Asnake Kefale (2003), 'The Politics of Federalism in Ethiopia: Some Reflection', in Gana T. Aaron \& Egwu G. Samuel (eds.), Federalism in Africa: Framing the National Question, p. 261.

${ }^{77}$ Aalen, Ethnic Federalism and Self-Determination, supra note 74, p. 256.

78 Nigussie Afesha (2016), 'The Ethiopian Constitutional Promises to the Nation and Nationalities: The Myth and Reality', Bahir Dar University Journal of Law, Vol. 6, No. 2.

${ }^{79}$ Gedion T. Hessebon and Abduletif K. Idris, supra note 41, p. 181.

${ }^{80}$ A Proclamation to Provide for Licensing and Administration of Advocates and Paralegals Practicing at Southern Nations, Nationalities and Peoples' Regional State Courts (Proclamation No 164/2016).
} 


\section{Cassation over Cassation}

According to Article 80(1) of the FDRE Constitution, the Federal Supreme Court has "the highest and final judicial power over federal matters". It also has an appellate jurisdiction over the decisions of State Supreme Courts on federal matters (Art. 80/6). Article 80(3)(a) of the FDRE Constitution allows the Federal Supreme Court to have "a power of cassation over any final court decision containing a basic-error of law". Likewise, State Supreme Courts have "the power of cassation over any final court decision on State matters which contains a basis error of law". ${ }^{81}$

Although State Supreme Courts have the power of cassation over any final court decision on State matters, the Federal Supreme Court Cassation Division has been reviewing decisions rendered by Supreme Court Cassation Division of regional states, on State matters, if the decision is contested on the ground that it contains a basic error of law. Accordingly, the same case may be reviewed twice if it is challenged for containing a basic error of law. This causes cassation over cassation, i.e., reviewing a decision which was reviewed by the Cassation Division of the State Supreme Court for basic error of law. In effect, "[a] decision of any court in Ethiopia today can be reviewed by the Cassation Division of the Federal Supreme Court if it manifests a prima facie case for basic error of law and if it is a final decision and is filed within the time limit" ${ }^{\prime \prime 2}$

This raises the question whether cassation over cassation violates the spirit and logic of regional state autonomy promoted in the FDRE Constitution. Muradu explains the opposing views with respect to the power of cassation over cassation. The first argument is that the power of cassation over cassation is not in congruity with the law if the matter was originally reviewed based on state law. And, it (the federal Cassation Division) may rightly review cases decided by state supreme and high courts on federal matters delegated to them.

On the other hand, there are persons who argue that "the practice of the division is in conformity with the spirit and the closer reading of the law defining its jurisdiction" ${ }^{83}$ Muradu, while stating the first position, indicates that power of the Federal Supreme Court Cassation Division to review cases decided by state supreme and high courts on federal matters delegated to them corresponds with horizontal distribution of power between the centre and the regional state. It should be noted that many do not object the cassation power of the Federal Supreme Court over cassation decisions of regional supreme courts

\footnotetext{
${ }^{81}$ FDRE Constitution, Article 80(3)(b)

${ }^{82}$ Muradu Abdo (2007), 'Review of Decisions of State Courts over State matters by the Federal Supreme Court', Mizan Law Review, Vol. 1 No.1, p. 60

${ }^{83}$ Id., p.62
} 
that involve cases adjudicated based on delegation power. ${ }^{84}$ However, Mehari contests the cassation power of regional state supreme courts if the case involves delegated federal power because the Cassation Bench of the State Supreme Court cannot render final decision on federal matters. ${ }^{85}$

In this regard, Semahegn notes that "the Federal Supreme Court has the power of cassation over any final court decision containing a basic error of law" and he states that "[i]t is dubious how the Federal Supreme Court has such power of cassation without any appellate jurisdiction over the decisions of regional courts." 86 Gedion and Abduletif argue that setting cassation over cassation on decisions of regional state courts (on state matters) is very problematic and seems to run counter to the spirit and logic of the federal arrangement established in the Constitution. ${ }^{87}$

One may thus question the cassation power of the Federal Supreme Court to review fundamental error of law over cases that do not involve federal matters. The federal government apparently defends the legislation as valid exercise of national authority, while regional state courts have done little to claim and maintain their supreme judicial authority over state matters. Regional states can, for example, take the matter to HoF and seek constitutional interpretation. A key factor that has inhibited regional states to confront such challenges (that infringe state autonomy) can be the reactions of the federal government through the vanguard political party system rather than addressing issues along with the federalism axis. This is directly linked with the existence of a dominant party system.

\section{Concluding Remarks}

Federal political systems have tiers of legislative, executive and judicial bodies. However, variation exists among federations in the distribution of judicial authority and the structure of courts. The FDRE Constitution has established federal and state courts, each with its own independent court structures and administrations. The Constitution also states the jurisdiction of federal and state courts. Hence, federal courts are authorized to see cases of federal matters while state courts are entitled to handle regional matters. However, there are problems

\footnotetext{
${ }^{84}$ Id., p. 64

${ }^{85}$ Mehari Redae (2015), 'Cassation over Cassation and its Challenges in Ethiopia', Mizan Law Review, Vol. 9, No.1, p 175.

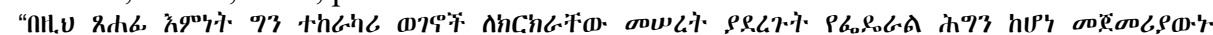

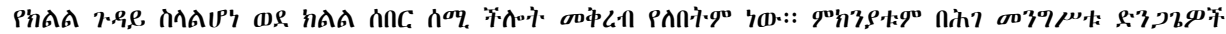

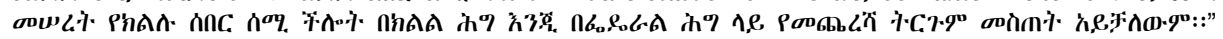

${ }^{86}$ Semahagn Gashu, supra note 1, p. 196

${ }^{87}$ Gedion T. Hessebon and Abduletif K. Idris, supra note 41, p. 181
} 
relating to the clarity as to what constitutes federal matters and which matters are reserved to state courts.

One can generally use Articles 51, 52 or 55 of the Constitution to categorize subject matters into federal and state matters. However, there are matters (such as contract, tort and persons) that are difficult to categorize into federal or state matters by using Articles 51,52 or 55 of the Constitution. The discourse on federal and state matters is important to determine the amount of compensatory budget that regional state courts would receive from the Federal Supreme Court in exercising delegated federal powers. The Federal Supreme Court pays nominal compensatory budget to the state Supreme Courts without considering the number of federal cases seen in these courts.

The other concern that is examined in this article relates to the cassation over cassation power of Federal Supreme Court (even in cases that involve state matters). Although the FDRE Constitution states that the Federal and State Supreme courts have the highest and final judicial power over federal matters and state matter respectively, the Federal Supreme Court has continued to review the cassation decisions of state Supreme Courts (on state matters) by citing the literal reading of Article 80(3)(a) of the FDRE Constitution which states that it has a power of cassation over any final court decision containing a basic error of law.

This needs constitutional interpretation by the House of Federation because reasonable interpretation based on the objectives and spirit of the Constitution (which ensures regional state autonomy) does not envisage the involvement of the Cassation Division of the Federal Supreme Court in cases that are state matters. The other option for regional states (other than taking the matter to the HoF for valid interpretation) is to initiate constitutional amendment that can rectify the ambiguity. 